\title{
THE EFFECT OF HEAT TREATMENT ON HARDNESS AND DRY WEAR PROPERTIES OF A SEMI-SOLID PROCESSED ALUMINIUM ALLOY
}

\author{
S. Menargues ${ }^{1}{ }^{*}$, M. Campillo ${ }^{1}$, M. T. Baile ${ }^{1}$, J. A. Picas ${ }^{1}$, A. Forn ${ }^{1}$ \\ ${ }^{1}$ Light Alloy and Surfaces Treatment Design Centre (CDAL), Rambla de l'Exposició 24, 08800 \\ Vilanova i la Geltrú (Barcelona), Spain.
}

\begin{abstract}
Semisolid AlSiMg casting alloys are attractive alternatives for automotive and aeronautical applications. In this work the effects of heat treatments on hardness and tribological properties of A356 aluminium alloy obtained by Sub-Liquidus Casting (SLC) were studied. The optimum heat treatment conditions, in which the material presents the maximum hardening and wear resistance values, were determined. Heat treatment conditions investigated included: A356 SLC as cast, T5 and T6. Furthermore, AC-46500 and A6061/T6 were analyzed for comparison. The tribological properties of the samples were investigated by pin-on-disc tests at $5 \mathrm{~N}$ and 0.05 and $0.1 \mathrm{~m} \cdot \mathrm{s}^{-1}$ in dry conditions. The samples were studied by SEM-EDX techniques in order to determine the wear mechanisms and the determination of the products produced during the tests. The maximum hardness and the lowest dry wear rate were obtained through T6 thermal treatment condition.
\end{abstract}

KEYWORDS: Semi-solid, Aluminium alloys, heat treatments, tribological properties.

\section{INTRODUCTION}

Sub-Liquidus Casting is a new semisolid casting method which offers better overall quality than conventional casting methods: less porosity, less contraction and the possibility of applying heat treatments.

In 2001, the THT Company [1] developed the Sub Liquidus Casting (THT-SLC) process in the USA. This process uses a small, compact machine shown in Figure 1.

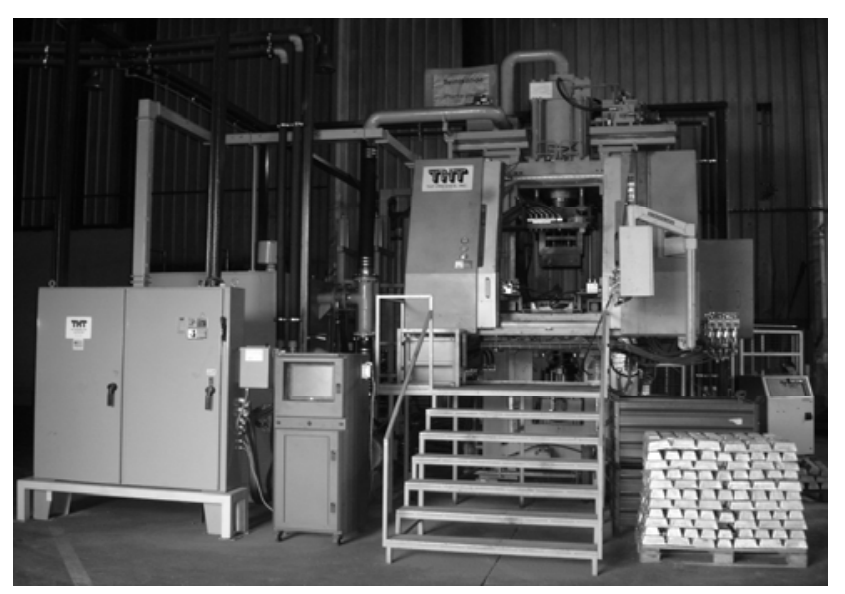

Figure 1: 400 ton THT press machine

THT machines have a vertical shot and horizontal die parting configuration. The THT machines are capable of considerably larger shots than conventional machines of higher tonnage and employ a large diameter and short shot approach.

This study compares the hardness and tribological properties of A356 components, produced by the SLC technique, in the as-cast, T6 and T5 tempers.

\section{BOUNDARY CONDITIONS}

The material used in this study was commercial SLC A356 alloy. The chemical composition is shown in Table 1.

Table 1. Chemical composition of the A356 alloy (wt.\%) [1]

\begin{tabular}{cccc}
\hline \multicolumn{4}{c}{ Chemical composition of the A356 alloy (wt.\%) } \\
\hline $\mathrm{Mg}$ & $\mathrm{Si}$ & $\mathrm{Cu}$ & $\mathrm{Fe}$ \\
$0.25-0.45$ & $6.50-7.50$ & $<0.20$ & $<0.20$ \\
\hline $\mathrm{Ti}$ & $\mathrm{Mn}$ & $\mathrm{Zn}$ & $\mathrm{Al}$ \\
$<0.20$ & $<0.10$ & $<0.10$ & Balance \\
\hline
\end{tabular}

The hardness of components heat treated to T5 and T6 tempers was assessed using the Brinell hardness test, performed in accordance with international standard EN ISO 6506-1, using a load of $62.5 \mathrm{~kg}$ and a ball diameter of $2.5 \mathrm{~mm}$.

The T5 and T6 heat treatments were carried out using a Hobersal HCV-125 forced air circulation oven with controlled cooling and a precision of $\pm 1^{\circ} \mathrm{C}$. In this study,

\footnotetext{
* Light Alloy and Surfaces Treatment Design Centre (CDAL) - Rambla de l'Exposició 24, 08800 Vilanova i la Geltrú (Barcelona), Spain. Phone 0034938967215. Fax 0034938967218. Email: $\underline{\text { sergi.menargues@upc.edu }}$
} 
the SLC A356 components (Figure 2) were cast with a 400 ton THT press machine.

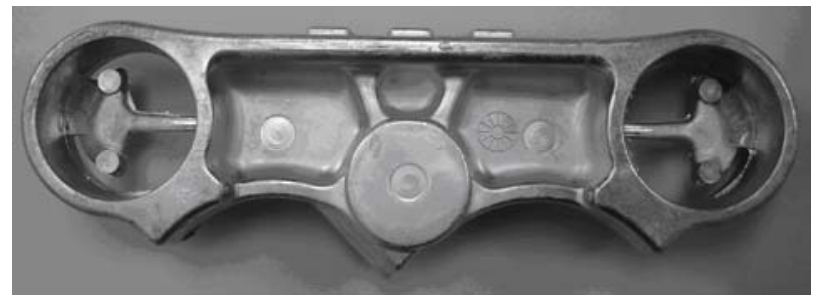

Figure 2: A356 component

Table 2 shows the temperatures, the solution times and the aging times used in the study.

\section{Table2: Heat treatment conditions}

\begin{tabular}{lll}
\hline Heat treatment & $\mathrm{T} 6$ & $\mathrm{~T} 5$ \\
\hline $\mathrm{T}$ solution $/{ }^{\circ} \mathrm{C}$ & 540 & - \\
$\mathrm{t}$ solution $/ \mathrm{h}$ & 3 & - \\
Tempering & Water at $25{ }^{\circ} \mathrm{C}$ & Water at $25^{\circ} \mathrm{C}$ \\
$\mathrm{T}$ of aging $/{ }^{\circ} \mathrm{C}$ & 170 & 170 \\
$\mathrm{t}$ of aging $/ \mathrm{h}$ & 3 & 10 \\
\hline
\end{tabular}

The Pin-on-Disc tests were performed in dry conditions, at $0.05 \mathrm{~m} \cdot \mathrm{s}^{-1}, 0.1 \mathrm{~m} \cdot \mathrm{s}^{-1}$, and with a load of $5 \mathrm{~N}$ until completing $2 \cdot 10^{4}$ laps. The specific wear rate was calculated using the transverse area of the worn channel, which was measured using a profile-roughness measuring unit.

\section{RESULTS AND DISCUSSION}

\subsection{BRINELL HARDNESS}

The average Brinell hardness of as-cast components was $68 \mathrm{HBW}$. This value is bigger than the Brinell hardness obtained by gravity die casting. The Brinell hardness result for A356 T6 components was similar to A6061 T6 forging alloys [2] and nodular cast iron with a ferritic matrix.

\subsection{MICROSTRUCTURE}

As cast microstructure of both castings show that phases are uniformly distributed. The figures clearly show a morphological change in the microstructures. In conventional cast sample, the microstructure is fully dendritic whereas in SLC sample, the primary dendrites are fragmented due to mechanical stirring [3].

The primary $\mathrm{Al}$ dendrites are plastically deformed during rheocasting processing [3].

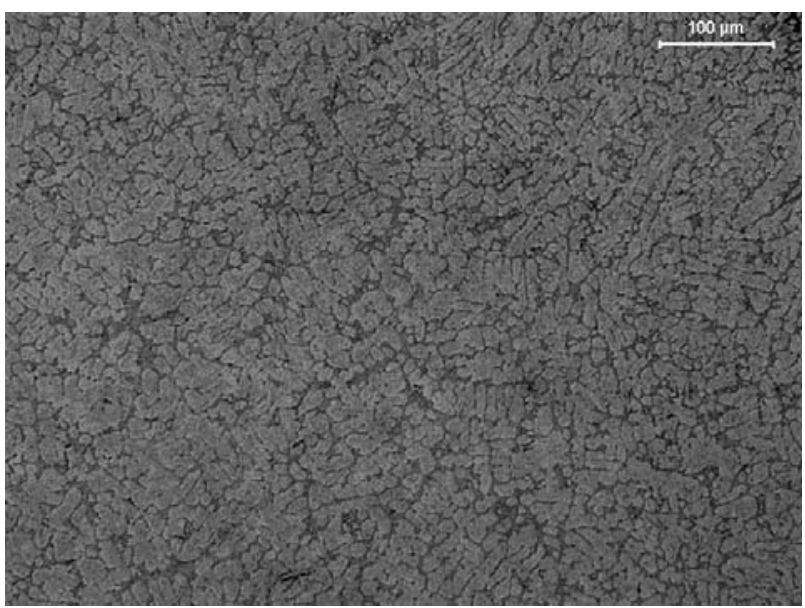

Figure 3: micrograph of gravity die casing microstructure

As-cast microstructure of SLC A356 alloy consists of small grains of primary $\alpha$-aluminium solid solution surrounded by the Al-Si eutectic (Figure 4). The semisolid injection process and the addition of refraining grain as TiB2 for determine the shape and distribution of the different phases such us $\mathrm{Mg} 2 \mathrm{Si}, \beta-\mathrm{Al} 5 \mathrm{FeSi}$ and $\pi$ $\mathrm{Al} \mathrm{Mg} 3 \mathrm{FeSi} 6$ [4].

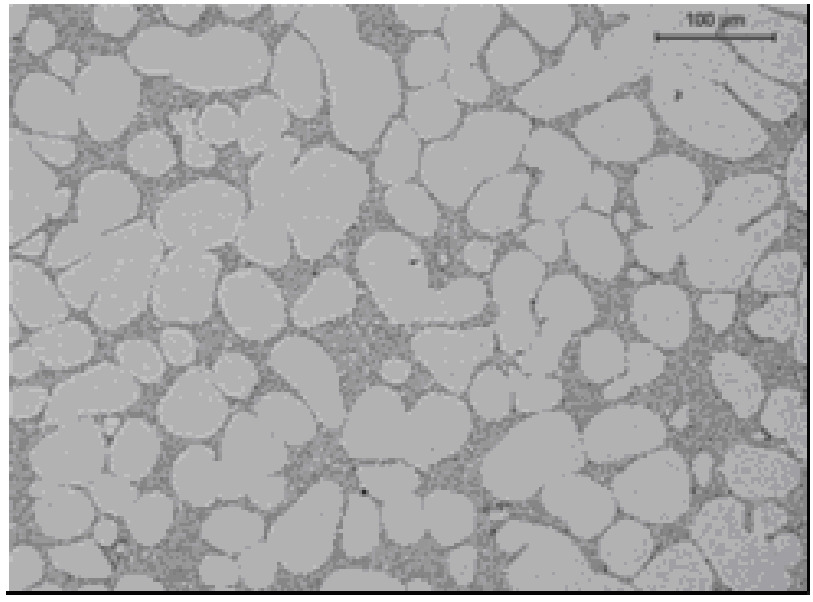

Figure 4: micrograph of SLC as-cast microstructure

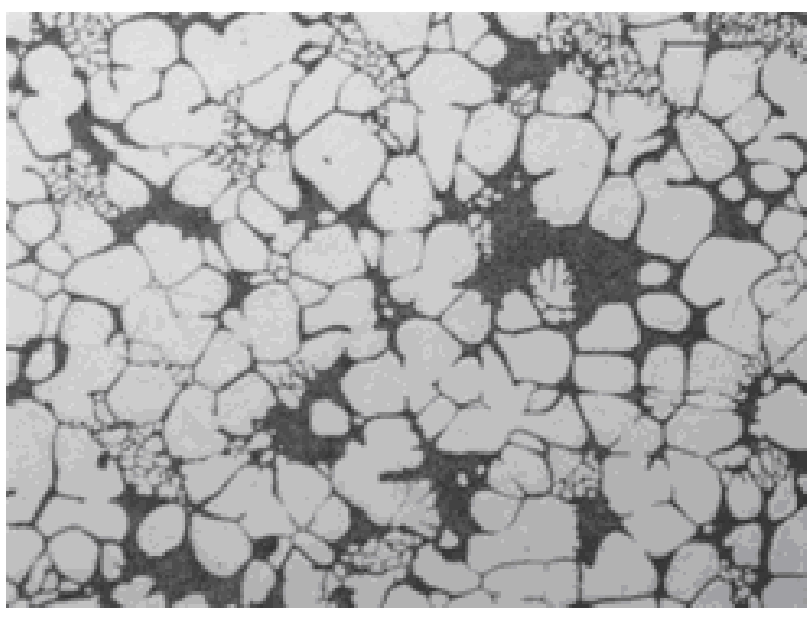

Figure 5: micrograph of the SLC T5 microstructure 
The micrographs in Figures 5 and 6 show the microstructures obtained with the $\mathrm{T} 5$ and $\mathrm{T} 6$ treatments. The eutectic silicon can be seen to coarsen considerably to the structure of the as-cast material (Figure 4).

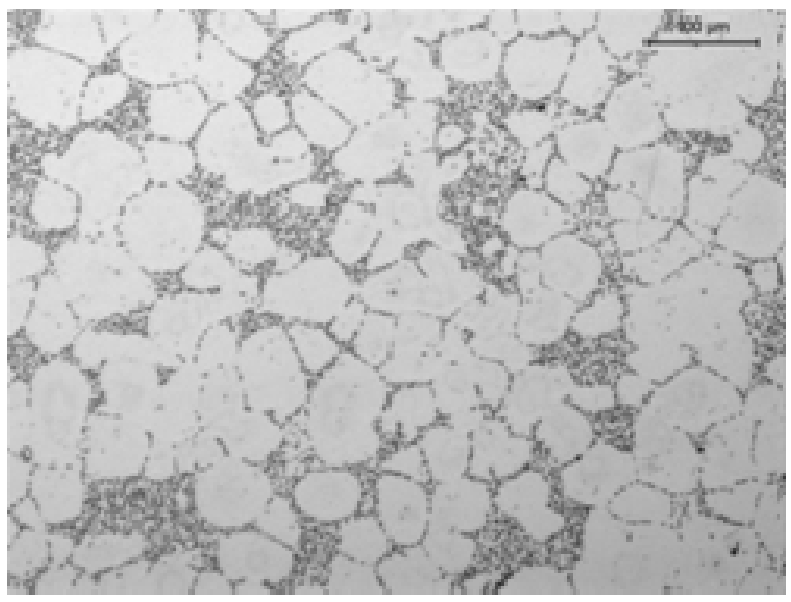

Figure 6: micrograph of the SLC T6 microstructure

\subsection{ROUGHNESS AND TRIBOLOGICAL PROPERTIES}

After the Pin on disc experiments the sliding wear rate of samples was calculated from the measurement of the wear track area, according to ASTM wear testing standard G-99. The results of the pin on disc test under dry conditions are summarised in Table 3.

Results of friction tests, at $0.10 \mathrm{~ms}^{-1}$ and $5 \mathrm{~N}$ of load, are presented in Figure 7. It is obvious that T6 of test specimens has a significant effect on the friction coefficient value for the applied velocity range [5]. It can also be noticed that all materials show a bigger specific wear rate to at low velocities (Table 3).

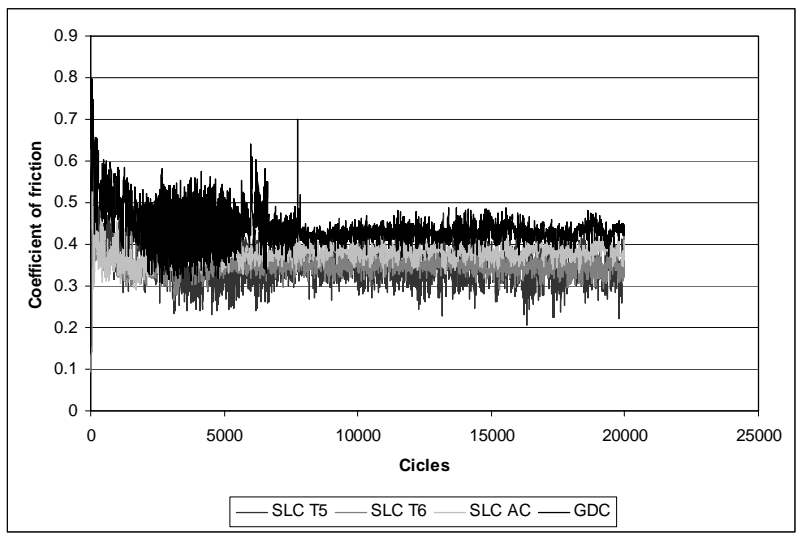

Figure 7: Coefficient of friction vs. cicles for $5 \mathrm{~N}$ and $v=0.1 \mathrm{~ms}^{-1}$.

The specific wear rate of as-cast sample is significantly higher than A356-T5 and A356-T6.
Table 3: Tribological properties

\begin{tabular}{|c|c|c|c|c|c|}
\hline $\begin{array}{c}\text { Vel. } \\
{\left[\mathbf{m} \cdot \mathbf{s}^{-1}\right]}\end{array}$ & Sample & $\begin{array}{c}\text { Hard. } \\
\text { [HBW] }\end{array}$ & $\begin{array}{c}\mathbf{R a} \\
{[\mu \mathrm{m}]}\end{array}$ & $\begin{array}{c}\text { Friction } \\
\text { Coeff. }\end{array}$ & $\begin{array}{c}\text { Specific Wear } \\
\text { rate } \\
{\left[\mathrm{m}^{3 / \mathrm{m}} \cdot \mathrm{N} \times \mathbf{1 0}^{-13}\right]}\end{array}$ \\
\hline 0.05 & $\begin{array}{l}\text { A356 } \\
\text { SLC } \\
\text { AC }\end{array}$ & 68 & 0.3 & 0.38 & 9.2 \\
\hline 0.10 & $\begin{array}{l}\text { A356 } \\
\text { SLC } \\
\text { AC }\end{array}$ & 68 & 0.3 & 0.40 & 5.3 \\
\hline 0.05 & $\begin{array}{l}\text { A356 } \\
\text { GDC }\end{array}$ & 79 & 0.3 & 0.43 & 12.2 \\
\hline 0.10 & $\begin{array}{l}\text { A356 } \\
\text { GDC }\end{array}$ & 79 & 0.3 & 0.44 & 6.5 \\
\hline 0.05 & $\begin{array}{c}\text { A356 } \\
\text { SLC } \\
\text { T5 } \\
\end{array}$ & 89 & 0.3 & 0.31 & 4.6 \\
\hline 0.10 & $\begin{array}{c}\text { A356 } \\
\text { SLC } \\
\text { T5 }\end{array}$ & 89 & 0.3 & 0.35 & 3.3 \\
\hline 0.05 & $\begin{array}{c}\text { A356 } \\
\text { SLC } \\
\text { T6 }\end{array}$ & 119 & 0.3 & 0.27 & 3.8 \\
\hline 0.10 & $\begin{array}{l}\text { A356 } \\
\text { SLC } \\
\text { T6 }\end{array}$ & 119 & 0.3 & 0.35 & 2.1 \\
\hline 0.05 & $\begin{array}{c}\text { AC- } \\
46500\end{array}$ & 98 & 0.3 & 0.40 & 5.9 \\
\hline 0.10 & $\begin{array}{c}\text { AC- } \\
46500 \\
\end{array}$ & 98 & 0.3 & 0.42 & 3.5 \\
\hline 0.05 & $\begin{array}{c}\text { A6061 } \\
\text { T6* }\end{array}$ & 116 & 0.3 & 0.34 & 3.8 \\
\hline
\end{tabular}

The friction coefficient increases with lineal velocity, and the specific wear rates decreases when the hardness increases.

The results of A356 as-cast samples are worse than a conventional cast alloy (EN AC-46500), but the results of A356 T6 samples are better than the forge alloy: A6061 T6 (Table 3).

\subsection{WEAR MECHANISMS}

From a general point of view, the worn surfaces show a combination of adhesive-abrasive wear (Figures 8-11).

During wear run the worm particle debris agglomerated and stick to the grooved surfaces. This is very prominent in case of a gravity die casting samples (Figure $8 b$ ).

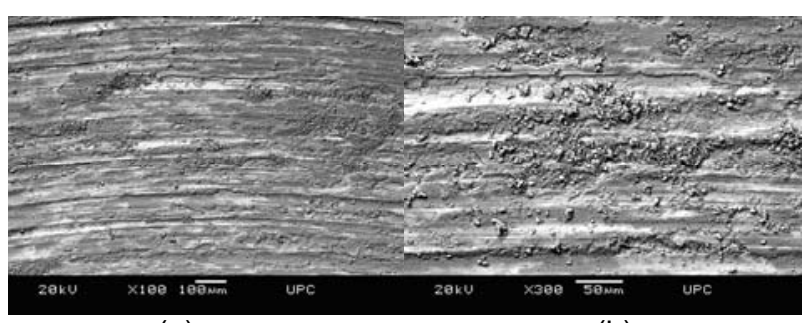

(a)

(b)

Figure 8: A SEM micrograph showing the worm surface of gravity die casing samples $v=0.05 \mathrm{~m} \cdot \mathrm{s}^{-1}$ 
The worn surfaces of SLC as-cast sample reveal an adhesive wear occurring by partial delamination of surface and causing grooves (Figure 9).

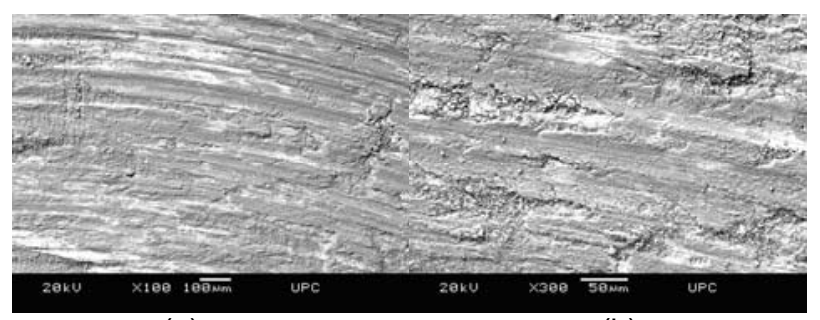

(a)

(b)

Figure 9: A SEM micrograph showing the worm surface of SLC as-cast samples $v=0.05 \mathrm{~m} \cdot \mathrm{s}^{-1}$

By increasing the hardness, the material is removed from the surface and the third body abrasion starts to dominate. The wear tracks on T5 sample surfaces show little evidence of scratching and fractures (Figure 10).

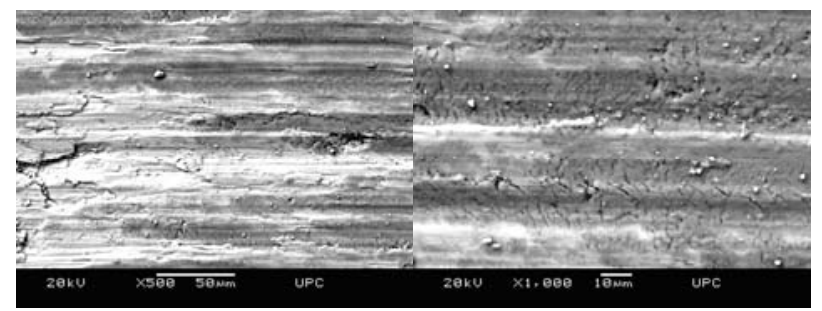

(a)

(b)

Figure 10: A SEM micrograph showing the worm surface of SLC T5 samples $v=0.05 \mathrm{~m} \cdot \mathrm{s}^{-1}$

Significant fractures and very large and deep grooves are generated on T6 sample surfaces (Figure 11a), evidencing the impact of third body abrasion (Figure 11b).

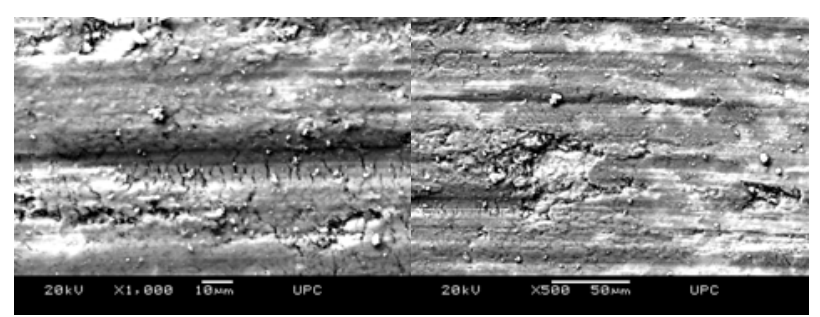

(a)

(b)

Figure 11: A SEM micrograph showing the worm surface of SLC T6 samples $v=0.05 \mathrm{~m} \cdot \mathrm{s}^{-1}$

\section{CONCLUSIONS}

The maximum hardness was obtained in A356-T6 samples with 3 hours of heat treatment at a solution temperature of $540^{\circ} \mathrm{C}$, RT water quenching and 3 hours of aging at $170{ }^{\circ} \mathrm{C}$.

Wear resistance of heat treated specimens was higher and was related to better mechanical characteristics, particularly with their increased hardness. Overall better wear resistance of SLC material, compared to the originally alloy, was attributed mainly to their higher silicon content and favourable distribution if Si particles of a relatively small size.

T6 Heat treatment has influence on a friction coefficient values at lower velocities.

Under the conditions described here the friction coefficient value increases with lineal velocity.

The specific wear rates and friction coefficient value increases when the hardness of the matrix increases due to heat treatments.

The SEM micrographs of the worn surfaces of the heat treated materials show that by increasing material hardness the wear mechanism gradually changes from an adhesive mechanism with plastic flow of material to an adhesive-abrasive mechanism with evidence of microcracking in the wear track.

\section{ACKNOWLEDGEMENT}

The authors wish to express their gratitude to Spain's Comisión Interministerial de Ciencia y Tecnología (CICYT) for its financial support under project $\mathrm{n}^{\mathrm{o}}$ DPI2005-02456 and INFUN S.A. for the use of the facilities to produce the components.

\section{REFERENCES}

[1] J. L. Jorstad: Economical Semi Solid Metal (SSM) Processing of Automotive Components J.L.J.Technologies Inc. SAE 2002.

[2] E. Rupérez. Tesis Doctoral: Efecto de las partículas de refuerzo en las propiedades del material compuesto A6061/A12O3p. Septiembre 2007.

[3] A.K. Dey, P. Poddar, K.K. Singh, K.L. Sahoo, Effect of thixocasting and heat treatments on the tribological properties of hypoeutectic Al-Si alloy. Materials Science and Engineering A 435-436 (2006) 521-529.

[4] Forn A., Baile, M ${ }^{a}$ T., Martín, E., "Effect of heat treatments in the silicon eutectic crystal evolution in Al Si alloys". Mat. Sci. Forum. Vols. 480-481, pp.367-372, (2005).

[5] A. Vencl, I. Bobic, Z. Miskovic, Effect of thixocasting and heat treatments on the tribological properties of hypoeutectic Al-Si alloy. Wear 264 (2008) 616-623. 